\title{
OUR PARTNERS' KEEPERS? AGENCY DIMENSIONS OF PARTNERSHIP RELATIONSHIPS
}

\author{
Deborah A. DeMotT*
}

I

\section{INTRODUCTION}

Many distinctive consequences of the relationship among partners stem from applicable norms of agency law. The Restatement (Second) of Agency defines agency as "the fiduciary relation which results from the manifestation of consent by one person to another that the other shall act on his behalf and subject to his control, and consent by the other so to act." Each partner is both an agent of her fellow partners and, as a member of the partnership, a principal. In a general partnership, each partner is an agent of the partnership for the purpose of its business; each partner's acts that apparently carry on partnership business in the usual way bind the partnership. Partnership-related knowledge or notice of any partner is imputed to the partnership, unless that partner is implicated in fraud on the partnership. Each member of a general partnership is also a principal; each is individually liable to third parties for the consequences of fellow partners' wrongful acts and for other partnership debts and obligations.

Basic agency norms applicable to incorporated businesses are fundamentally different. The baseline assumptions about the corporate form are that the corporation itself, not its owners, is the principal, that management is centralized into a hierarchical structure of directors, officers, and nonofficer managerial employees, and that shareholders risk no individual liability for corporate debts, beyond the amount they invested. In contrast, even in limited partnerships-which are more corporate-like as business forms-partnership norms often control the resolution of agency-related disputes. To be sure, basic agency norms applicable to partnership also recognize that not all of a partner's acts bind the partnership. Partners, like other agents, do not act on behalf of their fellow partners when they frolic on their own in nonpartnership activity. ${ }^{2}$

\section{Copyright $\odot 1995$ by Law and Contemporary Problems \\ * Professor of Law, Duke University.}

This article draws on material in my book-in-progress, Modern Law of Agency: Commercial Relationships of Trust, Confidence and Loyalty, to be published by Little Brown \& Co.

1. RESTATEMENT (SECOND) OF AGENCY \& 1 (1958).

2. The distinction between an extramural frolic, outside the agent's authorized scope of activity, and a mere detour from authorized acts originated in the case law concerning an employer's vicarious liability for employee negligence in driving vehicles. See Joel v. Morison, 172 Eng. Rep. 1338 (1834) (pedestrian knocked down by horse-pulled cart driven by servant; master would be liable if accident occurred during servant's slight detour from duty but not if it occurred during servant's own frolic); 
This article examines agency doctrines that are distinctive to the partnership context, exploring their consequences and rationales. These doctrines, among other things, operate to allocate the risk that a partner will engage in a transaction or commit an act that is detrimental to the partnership. Furthermore the doctrines allocate the risk of a partner's unauthorized transaction or act as between her fellow partners and third parties. Agency doctrine has the effect of specifying when a partnership as principal should communicate limits on a partner's agency authority to a third party and when a third party should inquire about the existence of such limits.

After beginning with the relevant statutory frameworks, this article turns to case law elaborations of agency doctrine. In particular, the article examines three recurrent partnership scenarios in which the underlying dispute implicates agency norms. In each scenario, an underlying issue is the extent to which we expect partners to be each other's keepers, that is, to monitor each other's actions. In the first scenario, the question is whether a partner's actions were conducted as a sideline frolic of the partner's own or whether the actions apparently carried on partnership business. In the second scenario, although the partner acted within the scope of partnership business, the act was wrongful as to third parties or fellow partners. This section of the article analyzes the implications for partnership of the varying justifications for imposing vicarious liability for another's wrongful act. The third scenario considers transactions entered into by a managing partner purportedly on behalf of an investment partnership that, in fact, were not properly authorized. Many such transactions involve dealings between the partnership and a lending institution. As between the lender and the investor-partners, who should bear the loss when the lender knows that the transaction is irregular, but the investor-partners demonstrably have been less than diligent in reviewing the activities of their managing partner?

II

STATUTORY FRAMEWORKS FOR BASIC AgENCY DOCTRINE

\section{A. Uniform Partnership Act (1914)}

Several provisions in the Uniform Partnership Act (the "UPA") embody in statutory form the common law of agency as it applies to partnerships. Section

Fiocco v. Carver, 137 N.E. 309 (N.Y. 1922) (infant passenger fell off side of truck driven by employee, in process of leaving street carnival far away from authorized route; employer is not vicariously liable for servant's negligence until, having greatly departed from his authorized route, frolicking servant returns to it).

A broad reading of the frolic concept has a central thematic role in an ambitious recent work of literary fiction. See WILLIAM GADDIS, A FROLIC OF HIS OWN (1994). As another character explains it, the central character's frolic-writing a "longwinded play about his grandfather"-illustrated his penchant for "blaming those faceless ogres out there instead of looking inside at the ogres we don't want to see . . . " Id. at 398. 
9(1) of the UPA makes each partner an agent "for the purpose of [the partnership's] business" ${ }^{3}$ but limits such authority to acts "for apparently carrying on in the usual way the business of the partnership ...." Section 9(1) combines two basic concepts of agency law, actual and apparent authority. An agent has actual authority to do an act if the agent reasonably interprets the principal's conduct to believe that the principal desires him so to act. ${ }^{4}$ An agent has apparent authority to do an act if the principal's conduct causes a third party reasonably to believe the principal consents to the act being done for him by the person purporting to act as his agent. ${ }^{5}$ A partner's act outside the ambit of section 9(1) does not bind the partnership unless it is authorized by the other partners or the other partners have abandoned the business. If the partnership restricts a partner's authority to act on its behalf, the partnership is not bound to persons with knowledge of the restriction by a partner's act in contravention of the restriction. Thus, to restrict a partner's agency authority to do acts that apparently carry on partnership business in the usual way, the partnership has the burden of communicating the restriction to third parties. If a partner conveys real property that belongs to the partnership, UPA section 10 binds the partnership to a conveyance executed in partnership name. ${ }^{6}$ The partnership may nonetheless recover the property if the transaction is outside UPA section $9(1)$, unless the property has been reconveyed after the initial grant to a holder for value without knowledge that the conveying partner exceeded his authority. Section 10 , then, ultimately protects the innocent holder for value over fellow partners victimized by a partner's conveyance outside the ordinary course of partnership business, when an interim reconveyance to the holder has occurred.

Like general norms of agency law, those specific to partnership estop parties from denying the truth of representations about their relationship when a third party relies to its detriment on the representation. Third parties who rely on false representations that a person is a partner (who in fact is not) are protected by UPA section 16; a person who falsely represents himself to be a partner of another, and a person who consents to such a representation being made about him, are liable to a third person who "on the faith of such representation" gives

3. Section 9(1) includes as the act of any partner, "the execution in the partnership name of any instrument ...." UNIF. PARTNERSHIP ACT \& 9(1) (last amended 1914), 6 U.L.A. 132 (1969). Only a signature in the partnership's name binds the partnership on negotiable paper. See Lund v. Chemical Bank, 797 F. Supp. 259, 267 (S.D.N.Y. 1992). Other cases hold that if a transaction is an ordinaryseeming one in the course of partnership business, a partner who executes a transactional document, such as a lease or a sales agreement, binds the partnership even if she does not specify that she signs as a partner. See, e.g., Firestone Fin. Corp. v. Owens, 419 S.E.2d 830 (S.C. Ct. App. 1992). Some authority disapproves of the "devious" use of a signature of a corporate officer who signs on behalf of a corporation purporting to act as an agent for the partnership. Haury \& Smith Realty Co. v. Piccadilly Partners I, 802 S.W.2d 612, 615 (Tenn. Ct. App. 1990).

4. RESTATEMENT (SECOND) OF AGENCY $\$ 26$ (1958).

5. $1 d . \$ 27$.

6. See Bracken v. Means, 631 So. 2d 178, 183 (Miss. 1994) (partner executed deed of trust conveying partnership property as security for refinancing loan). 
credit to "the actual or apparent partnership." A person about whom such a representation is made does not, however, have a categorical duty to repudiate the representation, since only "consent" to the representation would expose such a person to liability. This limitation makes practical sense. Suppose I learn that you are falsely claiming to be my partner. If I have done nothing to induce you to make the claim, and if I do not consent to your false representation, I would justifiably resent bearing the cost of notifying all to whom you may have made the representation that it is false. In contrast, it is not as cumbersome for third parties to inquire of me.

As principals, partners are bound by their fellow partners' acts as agents, and, as principals, partners have individual liability for the consequences of their agents' acts. UPA section 15 makes partners jointly and severally liable in two instances. Partners are jointly and severally liable for partnership liabilities under UPA section 13, which governs loss or injury suffered by any nonpartner caused by the wrongful act or omission of any partner acting either in the ordinary course of partnership business or with the authority of his fellow partners. Partners also have joint and several liability for partnership liability under UPA section 14, applicable to a partner's misapplication of money or property received by the partnership in the course of business or received by a partner acting within the scope of his apparent authority. Partners are jointly liable under UPA section 15(b) for all other debts and obligations of the partnership. ${ }^{8}$

Underlying the operation of these bodies of law is an implicit, and perhaps obvious, restriction on the efficacy of limitations on agents' authority. In the partnership context, as in the ambit of agency generally, limitations on authority are ineffective as to third parties if the restrictions are triggered, after the fact, by the consequences of the agent's act. The employment doctrine of respondeat superior affords many illustrations of this basic principle. An employer who requires its employees to drive vehicles in the course of their work cannot limit its vicarious liability for the employees' negligence by placing in written employment agreements a caveat: "You will have exceeded your authority to drive if you are determined to have driven negligently." The same restriction applies in the partnership context. UPA section 14, for example, would invalidate a provision in a partnership agreement that, by deeming improper use of funds to be unauthorized conduct, purported to eliminate partnership liability for a partner's embezzlement of client funds received in the course of partnership business. Likewise, in an investment partnership, the partnership is bound by partners' ordinary-seeming transactions in the course of its business-real estate, commodities, securities, art objects-even though the

7. UPA $\S 16,6$ U.L.A. at 195 . The elements of liability under $\S 16$ raise questions of fact, of course. See, e.g., Johnson v. Shaines \& McEachern, P.A., 835 F. Supp. 685, 689 (D.N.H. 1993).

8. This rule is not uniformly followed. See, e.g., Chase Bank v. Acosta, 880 P.2d 1109, 1114-15 (Ariz. Ct. App. 1994) (applying ARIZ. REV. SrAT ANN. \& 29-215 (1994), which makes partners jointly and severally liable for all partnership debts and obligations). 
partnership agreement treats as an unauthorized act any transaction through which the partnership loses money. A third party could, of course, agree to terms that assured the partnership it would not lose, but a general limit, operating retrospectively, on partners' authority in the partnership agreement does not bind a third party who lacks knowledge of the limit.

Fellow partners do, however, have remedies against their errant fellows even when agency norms protect the third party. ${ }^{9}$ UPA section 21 makes partners accountable as fiduciaries if they benefit individually and without the consent of fellow partners through a transaction in connection with partnership formation, conduct, or liquidation. ${ }^{10}$ If an unauthorized act or transaction results in loss for the partnership (because it is liable to a third party), the errant partner, like any agent, is liable to the principal, that is, the partnership, for the loss caused it by the act or transaction. Indeed, an agent is liable to compensate her principal for loss caused the principal by any breach of duty by the agent. ${ }^{11}$ If the errant partner, though, is unable to satisfy the partnership's claim financially, the remedy afforded fellow partners is not fully satisfactory. Such is an ultimate risk of inadequate monitoring of fellow partners.

\section{B. Revised Uniform Partnership Act (1994)}

Although section 201 of the Revised Uniform Partnership Act ("RUPA") declares a partnership to be an entity, other RUPA provisions preserve the basic framework of agency norms described above, with a few modifications that principally affect transactions in real estate. ${ }^{12}$ Under RUPA section 306, partners are jointly and severally liable for partnership obligations, which eliminates the UPA's differentiated treatment between wrongful acts and breaches of trust versus other sources of liability. RUPA section 301(1) treats all partners as agents for apparently carrying on in the usual way the partnership's business, but the partnership is not bound by a partner's unauthorized act

9. If the partnership is not bound to the unauthorized transaction, purportedly made on behalf of the partnership, the third party would have an action against the errant partner for breach of her warranty of authority. See Farm Credit Bank v. FCB Ltd. Partnership, 825 F. Supp. 932 (D. Kan. 1993) (action against agent for breach of implied warranty of authority may sound in either tort or contract under Kansas law). All agents impliedly warrant their authority to persons with whom they deal purportedly on behalf of their principals. See RESTATEMENT (SECOND) OF AGENCY § 329 (1958).

10. If an individual's association with others is nonfiduciary in quality, that fact is relevant to whether the individual is a partner in the association. In Simpson v. Ernst \& Young, 850 F. Supp. 648 (S.D. Ohio 1994), the court considered whether an accountant formally designated a "partner" was truly a partner in the defendant accounting firm; the individual accountant alleged that his association with the firm was as an employee and that his termination by the firm violated federal and state age discrimination statutes, which are inapplicable to partners because they are "employers" rather than "employees." Finding the plaintiff to be an employee and not a partner, the court pointed to a number of factors, including his lack of both management authority and rights to examine the firm's books. Id. at 661-62. Additionally, the firm expressly terminated the plaintiff and other "partners" to ensure the financial gain of the decisionmaking partners, demonstrating to the court that "the element of coownership of the firm and consequent fiduciary relationship" was absent. Id. at 662 .

11. See RESTATEMENT (SECOND) OF AGENCY $\$ 401$ (1958).

12. REVISED UNIF. PARTNERSHIP ACT $\$ 201$ (last amended 1994)[hereinafter RUPA], 6 U.L.A. 295 (Supp. 1995). 
when the partner deals with a person who "knows or has received a notification" that the partner lacks authority. In contrast, UPA section 9(1) makes restrictions on authority effective only against persons with knowledge of them. For a person to receive a notification under RUPA section 102(d), either the notification must have come to the person's attention or it must have been delivered to his place of business or other locale held out as a place to receive communications. In any event, notification turns on communication targeted to a particular recipient, versus filing information in a publicly accessible document.

One innovation in RUPA facilitates the communication of limitations on a partner's authority and reduces the cost of such communication by permitting an alternative to specifically targeted communication. RUPA section 303 permits public filing of a "statement of partnership authority," which may state the authority or limitations on the authority of some or all partners. A person not a partner is deemed by section 303(e) to know of a limitation on the authority of a partner to transfer real property if a certified copy of the statement of authority containing the limitation is recorded in the office where transfers of the property would be recorded (and where, presumably, the statement could come to light during a title search). Otherwise, in dealings with current members of an ongoing partnership, a third person is not deemed to know of a limitation simply because the filed statement of authority contains it.

RUPA departs from the common law agency norm that permits a tort plaintiff to sue agent and principal jointly in an action stemming from the agent's tort and to recover a judgment against each. ${ }^{13}$ This agency norm does not require the judgment creditor to attempt first to collect the judgment from the agent before attempting to collect from the principal. RUPA section 307(d)(1), in contrast, provides that regardless of the nature of the underlying claim, a judgment creditor must first attempt to collect from the partnership before pursuing any individual partner. ${ }^{14}$ RUPA thus treats partners more as guarantors of the partnership's obligation than as true joint obligors.

\section{Limited Partnership Statutes}

Limited partnership statutes differ significantly in function from statutes applicable to general partnerships. A general partnership exists as a result of an association among persons as co-owners to carry on a business for profit. General partnership statutes embody common-law-based definitions and rules applicable to such associations. Limited partnership statutes, in contrast, are like corporation statutes in that they specify formal steps requisite to organizing an entity with defined characteristics, chief among them a limitation on investors' risk of loss to the amount invested. On the agency front, limited

13. See Restatement (SECOND) OF AGENCY \& 217B (1958).

14. RUPA $\$ 307(d)(1)$ accords with pre-RUPA statutes in some jurisdictions. See, e.g., Security State Bank v. McCoy, 361 N.W.2d 514 (Neb. 1985) (applying NEB. REV. STAT. § 25-316 (reissue 1985)). 
partnership statutes presuppose that management will be centralized in a general partner, whose partnership liability by definition may not be limited. General partners may, however, themselves be incorporated entities, which in theory limits the individual liability of the general partner's shareholders and officers, a limitation recognized as effective by many but not all courts. All jurisdictions in the United States have enacted some form of limited partnership statute; while most states' current legislation is patterned on the Revised Uniform Limited Partnership Act of 1976 ("RULPA"), a few states remain stalwart adherents of the original Uniform Limited Partnership Act of 1916 (the "ULPA"). RULPA itself was the object of significant amendment in 1985, but not all states otherwise adhering to RULPA adopted the amendments.

RULPA section 403(a) provides that, subject to the statute itself and the partnership agreement, a general partner "has the rights and powers and is subject to the restrictions of a partner in a partnership without limited partners." ${ }^{15}$ In such a partnership, questions of a partner's authority would be resolved by the norms of agency discussed above applicable to a general partnership. Under RULPA section 403(b), a general partner has "the liabilities of a partner in a partnership without limited partners to persons other than the partnership and the other partners," subject only to the statute itself; but a general partner's liabilities to the partnership and to the other partners are, additionally, subject to provision in the partnership agreement.

ULPA section 7 made it unattractive for a limited partner to be active in partnership business by providing that a limited partner who "takes part in the control of the business" in addition to exercising a limited partner's rights and powers shall become liable as a general partner. ULPA section 10 specified limited partners' rights narrowly, as rights to have the partnership keep books, to inspect and copy those books, to have on demand information of things affecting the partnership and a formal account of partnership affairs when just and reasonable, to have dissolution and winding-up by judicial decree, and to receive their share of profits and statutorily defined return of contributions. ULPA section 7 left vulnerable limited partners who took actions not embraced by section 10, in particular because ULPA section 7 did not define "control" except by negative implication through the specification of rights in section 10 .

In response, the 1976 version of RULPA specified a "safe harbor" of acts that by themselves would not constitute participation "in the control of the business." Additionally, RULPA section 303(a), although carrying over the language of ULPA section 7, provided that "if the limited partner's participation in the control of the business is not substantially the same as the exercise of the power of a general partner," the limited partner is liable only to persons who transact business with "actual knowledge of his participation in control." The 1985 amendment to RULPA section 303(a) dropped the "substantially the same" test and shifted from a test of third parties' knowledge to a test of their

15. RULPA $\S 403$ (a) (last amended 1985), 6 U.L.A. $311-12$ (Supp. 1995). 
reasonable belief. Under amended RULPA section 303(a), a limited partner who participates in the control of the business is liable as a general partner only to those persons who transact business with the partnership "reasonably believing, based on the partner's conduct, that the limited partner is a general partner." This test on its face does not require the third party to establish reliance on that belief, in contrast to the requisites to establish partnership by estoppel under UPA section $16 .^{16}$

III

\section{ENTREPRENEURIAL LAWYERS AND OTHER FROLICSOME PARTNERS}

Several of the statutory terms set forth above have, over the years, attracted distinctive bodies of case law interpreting statutory language in light of particular factual circumstances. Many cases consider whether, by engaging in a particular act subsequently disowned by fellow partners as unauthorized, a partner was engaged in partnership business and appeared to be so engaged "in the usual way." Of some significance in these cases is whether the fellow partners knew about prior similar activity. Such knowledge would be essential to a showing that the fellow partners either ratified the final unauthorized act at issue or that they waived or modified restrictions on the errant partner's authority. Agency doctrine operates in the partnership context to assess whether a partner's acts are sufficiently connected with the partnership to justify treating them as acts of the partnership itself. As in any case turning on agency norms, the party seeking to attribute the partner's act to the partnership has the burden of establishing authority. ${ }^{17}$ In a general partnership, in which by statute each partner has agency authority to act in the usual way for the purpose of partnership business, a partner may readily have authority even in the absence of any written statement to that effect. Much turns, then, on the definition of partnership business and the appearance of carrying it on in the usual way.

The doctrinal starting point is that a partnership is not bound by the consequences of a partner's activities that are evidently unconnected with the partnership's business, unless fellow partners authorized the activity or unless they ratified the conduct after the fact. Many simple cases illustrate this basic principle. In Risk $v$. Schilling, the partnership owned and operated a family farm. ${ }^{18}$ The partner resident on the farm premises also pursued tractor repair as a hobby in a building he maintained on the farm's land. The court held that the partnership was not liable for injuries suffered by a social guest of the resident partner, which stemmed from a mishap while the guest was observing

16. See Gateway Potato Sales v. G.B. Inv. Co., 822 P.2d 490, 497 (Ariz. Ct. App. 1991) (original RULPA $\S 303$, upon which Arizona statute is based, does not require "direct contact" between limited partner and third party when "substantially the same" test is met).

17. E.g., First Nat"l Bank \& Trust Co. v. Scherr, 467 N.W.2d 427, 430 (N.D. 1991).

18. 569 N.E.2d 646 (Ind. 1991). 
a tractor repair. ${ }^{19}$ Even though the other partners knew of the resident partner's hobby, and did not object to it, the plaintiff did not further establish that they authorized the hobby. ${ }^{20}$

Matters are more complex in a professional services partnership because the demarcation between a partner's sideline or frolic and the partnership's own business may be less than clear, especially to a client of the partnership. Although it is possible to identify issues relevant to the resolution of these cases, they reach outcomes that are not entirely consistent.

Consider first a factual scenario in which a partner in a law firm has a sideline investment business that the partner operates on law firm premises. Suppose the partner either makes investments ineptly or cheats his investment clients by misappropriating their funds or misrepresenting the nature of the investments. Dispositive to the outcome in some cases is whether the investment client had an attorney-client relationship with the partner or the partnership, such that the investment dimension of the relationship can be subsumed in a claim of legal malpractice. ${ }^{21}$ Even prior representation on unrelated matters may make the firm vicariously liable for the partner's investment misconduct. In Heine v. Colton, Hartwick, Yamin \& Sheresky, the court held that, although facts alleged by the plaintiff did not support an inference of an attorney-client relationship between himself and a law firm partner with respect to investment transactions, the partner and the law firm might nonetheless owe the plaintiff a fiduciary duty, a duty breached by the partner. ${ }^{22}$ The law firm had previously represented the plaintiff on noninvestment matters, and the partner could reasonably have foreseen that the plaintiff would rely on his position as a lawyer. ${ }^{23}$

Also significant is whether fellow partners knew about the investment sideline and tolerated it (for example, by permitting the partner to use the firm's resources). Fellow partners' knowledge, along with other circumstances, could well indicate that the firm's business included investing on behalf of clients. ${ }^{24}$ In Heine, the court noted that various of the partner's fellow partners allegedly invested in his deals ${ }^{25}$; if the fellow partners knew about the investment sideline, the court reasoned, the facts would support a claim that they actually authorized their partner to enter the investment business, or it might reasonably appear to a client that the firm had authorized the partner's investment

19. Nor was the partnership liable to the plaintiff on principles of premises liability, because the individual partner was the sole occupier/possessor of the building in which his tractor workshop was located. Id.

20. Id. at 647 .

21. See, e.g., Steinkopf v. Stone, 927 F.2d 1259, 1267 (1st Cir. 1991) (applying Massachusetts law); Atkinson v. Haug, 622 A.2d 983, 986 (Pa. Super. Ct. 1993).

22. 786 F. Supp. $360,367-68$ (S.D.N.Y. 1992).

23. Id. at 368 .

24. RESTATEMENT Of THE LAW Governing LAWYERS $\$ 79 \mathrm{cmt}$. d (Tentative Draft No. 7, 1994).

25. 786 F. Supp. at 368. 
activities. $^{26}$ In contrast, in Heath v. Craighill, Rendelman, Ingle \& Blythe, the partner obtained funds for investment from clients of his law firm. ${ }^{27} \mathrm{He}$ misappropriated the funds. The court held that the law firm was not vicariously liable for the misappropriation, even though the plaintiff testified that a jocular conversation about the sideline investments occurred in his presence between the partner and other partners and firm employees. ${ }^{28}$ For the court, it was dispositive that the firm's charter limited it to rendering legal services, the partner gave the plaintiff no assurance that the firm itself would handle his investment, and the plaintiff presented "no credible evidence" that other partners knew or should have known about his investment transaction with the plaintiff. ${ }^{29}$ The charter limitation itself is unpersuasive as a factor because the law firm did not establish that the plaintiff knew about it. Likewise, if the partner's investment activity appeared to be an authorized incident of the law firm's business, it is irrelevant that the partner did not represent that the firm itself would handle the plaintiff's investments.

Additional facets of agency doctrine support the outcomes reached in many of these cases. A principal may become liable for her agent's actions if she fails to notify third parties of the true facts while knowing that third parties believe the act to be authorized and that they might as a result change their positions. $^{30}$ Estoppel and apparent authority, in our context, operate similarly. Agency doctrine has also long encompassed the separate concept known as "inherent agency power," that is, the power of a general agent derived "not from authority, apparent authority or estoppel, but solely from the agency relation ...."31 Inherent agency power binds the principal when the agent does acts that usually accompany or are incidental to authorized transactions, if the third party reasonably believes the agent to be authorized. ${ }^{32}$ Judge Learned Hand justified its existence as reducing "constant recourse" to the principal by third parties with whom the agent deals. ${ }^{33}$ Practices of "constant recourse" impose costs on both the principal and on third parties, and the doctrine of inherent authority benefits principals in the long run by reducing such costs. ${ }^{34}$

26. Id. at $368-69$.

27. 388 S.E.2d 178 (N.C. Ct. App.), appeal denied, 395 S.E.2d 678 (N.C. 1990). The law firm in Heath was organized as a professional association, but the court said it "is liable on the same basis and to the same extent as a partnership." Id. at 181. The use of limited liability vehicles by professional services partnerships is discussed infra part IV.C.

28. Heath, 388 S.E.2d at 182.

29. Id.

30. RESTATEMENT (SECOND) OF AGENCY \& 8B (1958).

31. Id. § $8 \mathrm{~A}$.

32. Id. § 161 .

33. See Kidd v. Thomas A. Edison, Inc., 239 F. 405, 408, (S.D.N.Y.), affd, 242 F. 923 (2d Cir. 1917).

34. "In the long run it is of advantage to business, and hence to employers as a class, that third persons should not be required to scrutinize too carefully the mandates of permanent or semipermanent agents who do no more than what is usually done by agents in similar positions." RESTATEMENT (SECOND) OF AGENCY $\$ 161 \mathrm{cmt}$. a (1958). 
The significance of inherent agency power for our present discussion is that it imputes the agent's acts to the principal even when the plaintiff's reasonable belief in the agent's authority is in some sense mistaken. In Croisant v. Watrud, the defendant accounting firm argued that the plaintiff was mistaken in her belief that it had authorized a partner to collect and disburse funds for her because accountants did not, as a profession, regard such services as ones they usually offered to clients. ${ }^{35}$ The court held that the plaintiff's reasonable belief in authorization trumped the profession's own description of its function. ${ }^{36}$ If the profession's self-definition is not dispositive, the law firm's private charter limitation in Heath is even less compelling as a basis to establish that the partner's investment activities were not incident to law firm business.

\section{IV}

\section{MISCONDUCT COMMITTED WITHIN THE SCOPE OF PARTNERSHIP BUSINESS}

\section{A. Justifications for Vicarious Liability}

As a principal, a partnership is vicariously liable for wrongs committed by its partners (and employees and other agents) acting in the course of partnership business. Vicarious liability extends also to individual partners, for the most part regardless of their individual culpability. The latter principle of derivative liability is, unsurprisingly, highly unpopular among many partners, in particular members of professional service firms. Interestingly, the principle of vicarious liability has over time attracted divergent justifications, each with its own strengths and limitations. In the partnership context, two forms of vicarious liability are significant: the vicarious liability of the partnership itself and the derivative (or secondary) vicarious liability of individual partners.

An initial justification for imposing vicarious liability on any principal is that the principal benefits through her agent's acts and should bear, jointly and severally with the agent, the liability created by the agent's misdeeds. Agency cases often note that a principal anticipates economic benefits-for example, being able to conclude more transactions-in using any agent. Partners might anticipate benefit through the broad authority of fellow partners to act on behalf of the partnership. The force of the "benefit principle" as a justification is limited by the legal datum that it is no defense to the principal that either the agent's particular misdeed was of no benefit to her or the agent's entire service yielded no benefit. Perhaps, though, the relevant sense of benefit is the broader one of advantage anticipated by the principal at the outset of the relationship with the agent. In any event, the amount of the principal's liability is not limited to the value of the benefit generated by the agent, and the principal is 
not credited with an offset against liability in the amount of losses incurred through the agent's activity.

Additionally, the benefit principle does not explain the distinction drawn by agency doctrine between types of agency relationships. If the principal's relationship with the agent is employment, the principal is vicariously liable for the agent's torts committed when the agent was acting within the scope of employment. ${ }^{37}$ Outside employment relationships, the principal's $\cdot$ vicarious liability for agents' torts is much narrower; with some exceptions, a principal is not liable for physical harms caused by the negligence of nonemployee agents ${ }^{38}$ but is vicariously liable for a nonemployee agent's misrepresentation, defamation, and tortious institution or conduct of legal proceedings, if the agent commits these torts while acting within the scope of authority. ${ }^{39}$ Whether an agent is an employee or a nonemployee is an inquiry answered by the structure of the agent's relationship with the principal, ${ }^{40}$ in particular by whether the principal has the right to control the agent's physical conduct. ${ }^{41}$ The amount or type of benefit the principal received or anticipated through the relationship is irrelevant.

A second basic justification for vicarious liability is suppressed fault on the part of the principal-that is, when an agent acts wrongly, the principal often has failed to fulfill its own duty even if the principal's failure is not always provable. The diffusion of agency authority in a partnership means that hierarchically structured controls on organizational actors, typical of large corporations, are less feasible. In a partnership setting, the suppressed fault justification, if persuasive, implies that partners individually have duties to monitor fellow partners and nonpartner agents of the partnership. In contrast, in the prototypical corporation, management is a centralized function, and shareholders are not individually at risk if they neglect to monitor the corporation's agents. ${ }^{42}$ Suppressed fault as a justification does not explain why legal doctrine encompasses separate independent torts of negligent selection, hiring, supervision, and retention. Nor does it explain why the principal's demonstrable innocence is no defense: the principal is still liable even if she employed a state-of-the-art monitoring system to prevent and detect her agents' misconduct. ${ }^{43}$

37. See RESTATEMENT (SECOND) OF AGENCY $§ 219$ (1958).

38. See id. $\$ 250$.

39. See id. $\S \S 253-254,257$.

40. See id. $\S 220$.

41. See id. \& 2(1), (2).

42. This argument is consistent with the insight in Eugene F. Fama \& Michael C. Jensen, Separation of Ownership and Control, 26 J. L. \& ECON. 301, 316 (1983), that in large partnerships, "the sharing of liability and residual cash flows among important decision agents (the partners) ensures that large partnerships have strong versions of the mutual monitoring systems that we contend are common to the decision control systems of complex organizations." Mutual monitoring would typify partnerships.

43. In contrast, "control person" liability under the federal securities laws is unavailable against an innocent person. See Securities Act of 1933, \& 15, 15 U.S.C. \& 77o (1988) (controlling person not liable if she lacked knowledge of or reasonable ground to believe in facts on the basis of which controlled 
Finally, like the benefit principle, suppressed fault may prove too much. If partners individually have duties to monitor fellow partners, liability for breach of these duties would be direct not vicarious.

The third basic justification for vicarious liability is that it enhances the assets out of which an injured party can be compensated. ${ }^{44}$ In general, principals tend to be better suited than agents to bear the risk of financial loss. ${ }^{45}$ Vicarious liability, however, clearly is not limited to deep-pocket or even solvent principals. Nor is the plaintiff always required to make an initial attempt to collect from the agent before turning to the principal. ${ }^{46}$ Additionally, the compensation principle does not explain very well why the principal, as opposed to society's resources more generally, should have a duty to compensate when the principal did not benefit from the wrongful conduct and did not authorize it. ${ }^{47}$

Vicarious liability is susceptible to a fourth justification that is analytically more elegant: qui facit per alium, facit per se (one who acts through another acts through himself). Of venerable lineage, this maxim identifies the agent with the principal. ${ }^{48}$ The maxim, of course, is not literally true; its power is its usefulness as a figurative or heuristic device to help understand an agency relationship. ${ }^{49}$ The maxim supports the derivative liability of individual partners to the extent that partnership norms identify all partners with the acts of all fellow partners. In particular, under the UPA, the partnership itself was

person's liability would exist); Securities Exchange Act of 1934, § 20(a), 15 U.S.C. $\$ 78 t$ (1988) (controlling person not liable if acted in good faith and did not induce act constituting violation).

44. See Bair v. Peck, 811 P.2d 1176, 1182 (Kan. 1991) (stating that "[a]s a practical matter vicarious liability was recognized as a method of providing a source of recovery for the innocent victim of another's negligence when the actual tortfeasor was unable to respond financially for the damage caused").

45. See Alan O. Sykes, The Economics of Vicarious Liability, 93 YALE L.J. 1231, 1236 (1984).

46. ReSTATEMENT (SECOND) OF AGENCY § 217B (1958).

47. This point is especially compelling if one agrees with Professor Weinrib that justice within a private law regime requires correlativity of right and duty: this defendant should be liable to this plaintiff only when the defendant's breach of duty has infringed the plaintiff's right. Compensation fails as a free-standing rationale for imposing liability because its justificatory force applies solely to the plaintiff; it does not, correlatively, embrace the defendant as well. ERNEST J. WEINRIB, THE IDEA OF PRIVATE LAW 142-43 (1995). Nor does the compensation rationale explain the distinctions drawn by agency doctrine between types of agency relationships, a limitation it shares with the benefit principle.

48. Justice Story stated the maxim as "qui per alium facit per seipsum facere videtur" (one who acts through another is seen as acting himself). JOSEPH STORY, COMMENTARIES ON THE LAW OF AGENCY AS A BRANCH OF COMMERCIAL AND MARITIME JURISPRUDENCE $\$ 440$ (1839). Authorities trace the maxim itself to the dictum in Jones $v$. Hart that "whoever employs another is answerable for him.... The act of a servant is the act of his master." 90 Eng. Rep. 1225 (1698), discussed in J. DENNIS HYNES, AGENCY AND PARTNERSHIP 66-71 (4th ed. 1994).

49. The identification principle has long been characterized as a fiction. E.g., Oliver Wendell Holmes, Jr., Agency, 4 HARV. L. REV. 345, 347-51 (1891) (noting evolution of "fictitious" identification of agent with principal in history of doctrine of respondeat superior); John H. Wigmore, Responsibility for Tortious Acts: Its History, 7 HARV. L. REV. 315, $391-99$ (1894) ("[F]iction of Identification . . was merely a reason, an easy, lazy reason, which was put forward to sanction and support a rule of whose practical expediency the Courts were perfectly satisfied ...."). In contrast, Professor Weinrib characterizes the qui facit maxim as "the common law's invitation to view the employee's tort in a certain light [that] illuminates respondeat superior as an instantiation of corrective justice." WEINRIB, supra note 47 , at 187. 
formally characterized not as an entity but simply as an aggregate of its members. ${ }^{50}$ RUPA section 2.01 , in contrast, formally adopts an entity characterization. Other provisions in RUPA, however, continue to treat general partnerships as fluid collectivities by permitting any partner to dissociate by express will at any time, even if the dissociation breaches an express provision of the partnership agreement. ${ }^{51}$ The qui facit maxim itself does not specify limits to vicarious liability. It suggests, instead, a line of further inquiry, aimed at the question whether by its nature a particular wrongful act makes it unfair or implausible to identify the actor with the partnership and other individual partners.

A final approach to justifying vicarious liability analyzes consequences likely to follow in its absence and compares them with the consequences of imposing vicarious liability, whether limited to the partnership itself or imposed secondarily on individual partners as well. Particular consequences to consider would include changes in the behavior of third parties who deal with partnerships and changes in the behavior of partners. In the absence of any vicarious liability, third parties who knowingly deal with individual partners would have enhanced incentives to investigate that partner's reputation for competence and probity and her financial ability to compensate the third party for loss. Third parties would also have enhanced incentives to insure themselves against loss, including the risk of involuntarily or unknowingly becoming the creditor of a judgment-proof person. These incentives would be present, but to a lesser degree, if the partnership itself were vicariously liable although individual partners were not. The assets and insurance coverage of the partnership itself would be focal points for inquiry. Relatedly, fellow partners would have reduced incentives to monitor each other, especially if their individual assets were no longer at risk. Since monitoring requires effort or expenditures of resources, it is not free; lessened monitoring would save the costs associated with it. Life for third parties would be more cumbersome, with additional levels of caution, investigation, and insurance being necessary. ${ }^{52}$ Depending on the relative magnitude of all costs, these developments could run counter to the

50. See UPA \& 6, 6 U.L.A. at 22 (defining partnership).

51. See RUPA $\$ \$ 601(1), 602,6$ U.L.A. at 322, 325-326 (Supp. 1995).

52. The basic argument is that choices about vicarious liability carry implications that are explicable in terms of transactions costs for third parties as well as for a principal and her agent. Investigating and insuring consume time and assets. For an analysis of transactions costs focused on contracting between agents and principals, see Sykes, supra note 45 , at 1242-43. See also Richard A. Booth, Limited Liability and the Efficient Allocation of Resources, 89 Nw. U. L. REV. 140, 157 (1994) (characterizing rule of shareholders' limited liability in corporate context as "a contracting device" that puts burden on creditor "to protect himself rather than forcing the entrepreneur to specify the limits of liability").

An additional type of transaction cost stems from the third party's need for professional assistance in structuring its relationships. For example, recent commentary recommends that clients be able to enter into prospective waivers of lawyer malpractice liability if the client has independent legal representation before signing the release. Developments in the Law-Lawyers' Resonsibilities and Lawyers' Responses, 107 HARV. L. REV. 1547, 1671 (1994). The additional representation will not be provided for free, whether the lawyer who provides it is separately retained or is an employee of the client. 
point of agency doctrines, that, like the inherent authority doctrine discussed above, serve to reduce aggregate costs-including precautionary and insurance costs borne initially by third parties-of acting through individuals other than oneself. Additionally, if agents know that their principal actively monitors their activity, that knowledge may itself deter intentional misconduct and may induce agents to take additional care, thereby reducing negligent misconduct. Reduced monitoring reduces these consequences as well. However, abstract analysis yields no quantitative comparison of the magnitude of the third party's additional costs versus those saved by members of the partnership.

\section{B. Intentional Wrongs}

Partners who act wrongfully injure, in the first instance, either their fellow partners or third-party victims. Betrayal of fellow partners can take many forms, including making unauthorized use of partnership assets, ${ }^{53}$ forging checks on partnership accounts, ${ }^{54}$ and diverting ${ }^{55}$ or attempting to divert clients. $^{56}$ If the victim of the misconduct is a partner, would nonmalfeasant partners who are not themselves victims be vicariously liable to the victim? Following the qui facit maxim and identifying a partner's acts with all fellow partners would impute the wrongdoing to all partners, including the victim, and thus operate to bar recovery. Two recent cases reach outcomes consistent with this reasoning; they differentiate between an innocent general partner's liability exposure to creditors and exposure to limited partners, and hold that an innocent general partner is not vicariously liable to a limited partner or the limited partnership itself for a fellow general partner's misconduct. ${ }^{57}$ On the other hand, if the innocent partner has been negligent in allowing the active misconduct to occur, the "innocent" partner would be directly (not vicariously) liable for the consequences of her negligence ${ }^{58}$

Partners' vicarious liability to nonpartner claimants is not limited to situations in which a fellow partner acted negligently in the conduct of partnership business. A panoply of intentional torts and crimes also trigger

53. Lawson v. Rogers, 435 S.E.2d 853, 858 (S.C. 1993) (managing partners appropriated various cash revenues generated by hotel without assent of nonmanaging partners).

54. Barnhardt v. Barnhardt, 578 N.Y.S.2d 615, 616 (App. Div. 1992) (partner forged fellow partner's name on check representing payment of her share of partnership assets; other copartners not liable to bank for misappropriated funds).

55. Updike v. Wolf \& Co., 529 N.E.2d 993, 999 (Ill. App. Ct. 1988)(partner in accounting firm breached fiduciary duty by failing to disclose large cash payments made to him by firm clients), appeal denied, 535 N.E.2d 922 (IIl. 1989).

56. Butler, Fitzgerald \& Potter v. Beggans, 1994 WL 463966 (S.D.N.Y. Aug. 23, 1994) (lawyer proposed to firm clients that they compensate him personally for his services, which breached lawyer's fiduciary duty to firm because it was not disclosed to firm and it went beyond preliminary steps to compete).

57. In re Monetary Group, 2 F.3d 1098, 1107 (11th Cir. 1993); Kazanjian v. Rancho Estates, Ltd., 1 Cal. Rptr. 2d 534, 536 (Cal. App. 1991).

58. Beckman v. Farmer, 579 A.2d 618, $655-56$ (D.C. 1990). 
vicarious liability, including defamation, ${ }^{59}$ embezzlement, ${ }^{60}$ intentional infliction of emotional distress, ${ }^{61}$ securities fraud, ${ }^{62}$ racketeering, ${ }^{63}$ and intentional breach of fiduciary duty ${ }^{64}$ The dispositive question is whether the acts constitutive of the legal wrong were apparently done within the scope of partnership business. Some courts, however, differentiate remedies on the basis of partners' relative culpability. In particular, some courts decline to award punitive damages against nonculpable partners, unless the partnership itself authorized, ratified, controlled, or participated in the tortious conduct. ${ }^{65}$ The rationale for this restriction is that the function of punitive damages is to punish the wrongdoer and deter future misconduct. ${ }^{66}$ It is difficult to determine how far this limiting rationale extends if fewer than all partners authorized, ratified, or participated in the misconduct, since any partner might have the requisite authority to act in a manner that implicates the partnership. In contrast, demonstrating a corporation's complicity for these purposes requires showing the involvement of a superior officer or managerial agent, consistent with the hierarchical structure of authority necessary to bind a corporation. ${ }^{67}$ On the partnership front, other courts do not differentiate among partners' culpability in awarding punitive damages so long as the errant partner was acting in the ordinary course of partnership business. ${ }^{68}$ For that matter, even outside the

59. Colodny v. Iverson, Yoakum, Papiano \& Hatch, 838 F. Supp. 572, 576 (M.D. Fla. 1993) (alleged defamation written and published by partner in law firm in connection with its representation of clients).

60. Sheldon Co. Profit Sharing Plan \& Trust v. Smith, 828 F. Supp. 1262, 1281-83 (W.D. Mich. 1993) (partner in investment advisory firm embezzled from employee benefit plans managed by firm; partner's illicit activities used firm's stationery such that partner acted with apparent authority in the ordinary course of partnership business); Clients' Sec. Fund v. Grandeau, 526 N.E.2d 270, 273 (N.Y. 1988) (aggrieved clients of lawyer who embezzled their funds have claims against lawyer's partner even if he lacked knowledge of the embezzlements).

61. Cf. Meyer v. Park South Assocs., 552 N.Y.S.2d 614, 616 (App. Div. 1990) (individual general partner's alleged intentional infliction of emotional distress treated as tort committed by partnership).

62. Silverman v. Niswonger, 761 F. Supp. 464, 469-70 (E.D. Mich. 1991) (fraud allegedly committed by general partner not outside scope of authority).

63. Crowe v. Smith, 848 F. Supp. 1258, 1262-63 (W.D. La. 1994).

64. FSLIC v. McGinnis, Juban, Biven, Mullins \& Patterson P.C., 808 F. Supp. 1263, 1270-72 (E.D. La. 1992) (closing lawyer was acting within the scope of law firm business when he represented bank in real estate transaction; if failure to disclose conflict of interest constituted legal malpractice or breach of fiduciary duty, law firm and its partners would be vicariously liable).

65. In re WPMK Corp., 59 B.R. 991 (D. Haw. 1986) (applying Hawaii law); Husted v. McCloud, 436 N.E.2d 341 (Ind. Ct. App. 1982), vacated, 450 N.E.2d 491 (Ind. 1983); Duncan v. Henington, 835 P.2d 816 (N.M. 1992). In some cases, courts limit an individual partner's exposure to the excess value received over his proper partnership share. See Langness v. "O" Street Carpet Shop, 353 N.W.2d 709 (Neb. 1984). This principle does not protect partners who themselves breach a duty. Id. at 714; Beckman v. Farmer, 579 A.2d 618, 656-57 (D.C. 1990).

66. Duncan, 835 P.2d at 818.

67. See, e.g., Kemner v. Monsanto Co., 576 N.E.2d 1146, 1155-58 (Ill. App. Ct. 1991), appeal denied, 584 N.E.2d 130 (IIl. 1991). The corporate complicity rule is articulated in RESTATEMENT (SECOND) OF AGENCY $\$ 217$ (c) (1958) and RESTATEMENT (SECOND) OF TORTS $§ 909$ (1979).

68. See Winant v. Bostic, 5 F.3d 767, 775 (4th Cir. 1993) (applying North Carolina law); Blue v. Rose, 786 F.2d 349, 352-53 (8th Cir. 1986) (applying Missouri law); Meleski v. Pinero Int'l Restaurant, Inc., 424 A.2d 784 (Md. Ct. Spec. App. 1981); Duggins v. Guardianship of Washington, 632 So. 2d 420, 430 (Miss. 1994). 
partnership context, a few jurisdictions automatically impose vicarious liability for punitive damages on any employer, even when the individual tortfeasor was not a managerial agent, each time the employer is liable for compensatory damages. $^{69}$

The disparate justifications for vicarious liability help explain why courts diverge in their treatment of punitive damages in the partnership context. If the rationale for vicarious liability is the "benefit principle," it is hard to justify imposing liability for punitive damages on innocent partners when the malfeasant partner's conduct has not benefitted the partnership and instead has made all partners liable for compensatory damages. Likewise, imposing vicarious liability to deepen the asset base available to compensate victims is not a viable justification when the remedy is expressly extracompensatory. In contrast, the qui facit maxim directly supports all partners' vicarious liability for punitive damages, so long as the malfeasant partner's wrong does not, by its nature, destroy the plausibility of identifying all partners with the wrongdoer.

Other justifications for vicarious liability operate less tidily as applied to punitive damages. The suppressed fault principle operates ambiguously. The principle might be understood to create an irrebuttable presumption of active cooperation or negligently passive failure by the nonfeasant partners, thus making them vicariously liable for punitive damages. Or it might mean that the nonfeasant partners should have the burden of showing, to a high standard of proof, their total lack of culpability. Finally, consider whether a jurisdiction's rule respecting vicarious liability for punitive damages would enhance either the monitoring done by partners of each other's conduct or the precautionary costs incurred by third parties who deal with partnerships. In the absence of empirical data, no dispositive answer emerges from this inquiry. A rule imposing vicarious liability might well augment partners' incentives to monitor each other. Much intentional misconduct repeats prior misconduct and, if the initial misconduct is detected, subsequent repetitions can be prevented. ${ }^{70}$ The relevant comparison would be between the additional costs of augmented monitoring and the cost of the misconduct prevented or deterred by the monitoring. On the other hand, a rule barring automatic vicarious liability for punitives might not enhance third parties' precautionary costs so long as the partnership and its members remained vicariously liable for compensatory damages.

69. Johnson v. Rogers, 763 P. $2 \mathrm{~d} 771,776 \mathrm{n} .2$ (Utah 1988).

70. Concerning vicarious liability in the corporate context for agents' crimes, Professor Arlen has argued that increased corporate liability does not necessarily deter crime because it stimulates corporate expenditures on internal enforcement that also increase the probability that the government will detect the crime. See Jennifer Arlen, The Potentially Perverse Effects of Corporate Criminal Liability, $23 \mathrm{~J}$. LEGAL STUD. 833 (1994). Professor Arlen's argument is inapplicable to noncriminal contexts, which do not connect internal enforcement and monitoring to enhanced probabilities of governmental detection. See id. at 842 . 


\section{Our Partners' Keepers No Longer?}

Many state legislatures have been willing, over the years, to enact organizational statutes that formally hold out the promise that a co-owner of a professional services firm would not, as an individual, have vicarious liability for the consequences of professional malpractice committed by fellow owners or firm employees, unless she was individually implicated in the acts that constituted malpractice. This section of the article focuses on the use of such statutory vehicles by law firms. Starting in the 1960s, many law firm partnerships reorganized-or organized themselves initially-as professional corporations to obtain the tax advantages then available. ${ }^{71}$ Professional corporation statutes, for the most part, did not eliminate members' joint and several liability for malpractice ${ }^{72}$; while some state courts held that firm members retained individual partnership-based liability, other courts declined to impose such liability. ${ }^{73}$ More recently, states have enacted statutes authorizing limited liability companies ("LLCs") and limited liability partnerships ("LLPs") that expressly restrict members' individual liability to that arising from acts in which they individually participated. ${ }^{74}$ State courts, however, have authority to regulate the professional norms and circumstances under which lawyers may practice, and the extent to which they will embrace limits on partners' vicarious

71. Robert W. Hillman, Hillman on Lawyer Mobility 6:7 (1994).

72. See id. at 6:20. For example, N.C. GEN. STAT. § 55B-9(a) (1994) preserves liabilities between a licensee furnishing a professional service and the recipient of the service as well as "standards of professional conduct applicable" to the rendition of professional services; it expressly supersedes the effect of $\S 55 \mathrm{~B}-9(\mathrm{~b})$, which provides that professional corporation shareholders shall not be liable for the professional malpractice of others not at the time working under their supervision or direction, unless they were "directly involved in the specific activity" in which malpractice occurred.

73. See Wayne M. Gazur, The Limited Liability Company Experiment: Unlimited Flexibility, Uncertain Role, 58 LAW \& CONTEMP. PROBS. 135 (Spring 1995).

74. Richard C. Reuben, Added Protection, A.B.A. J., Sept. 1994, at 54, 56-57. For an existing professional services partnership to become an LLC, the partnership must be dissolved. In contrast, LLP statutes permit existing professional services partnerships, without dissolving, to register as LLPs. It is noteworthy that LLP statutes differ on major substantive issues. The most significant distinguishing point is whether the statute relieves members of an LLP from derivative vicarious liability on all claims against the partnership regardless of their nature or only on claims of professional malpractice. Compare MINN. STAT. ANN. § 323.14(2) (West Supp. 1995) (partner not individually liable for anything chargeable to partnership) and N.Y. PARTNERSHIP LAW § 26(b) (McKinney Supp. 1995) (partner not individually liable for any debts, liabilities or obligations of partnership) with DEL. CODE ANN. tit. 6 , $\S 1515$ (b) (Supp. 1994) (partner not individually liable on claim "arising from negligence, wrongful acts or misconduct, whether characterized as tort, contract or otherwise"), D.C. CODE ANN. § 41-146(a) (Supp. 1994) (partner not individually liable on claims "arising from errors, omissions, negligence, incompetence, or malfeasance"), N.C. GEN. STAT. § 59-45(b) (1994) (same), and TEX. REV. CIV. STAT. ANN. art. 61326-3.08(a)(1) (Supp. 1995) (same). Under statutes that restrict such liability only for malpractice-related claims, significant conflicts in economic interest may arise between partners who have individual liability on the malpractice claim and partners who do not. The partners with exposure to individual liability on the malpractice claim will prefer that partnership assets be used to satisfy that claim. The other partners, however, may not share this preference; each dollar in partnership assets used to satisfy the malpractice claim reduces the assets available to satisfy other creditors and to distribute to partners. For an extensive discussion, see Robert W. Hamilton, Registered Limited Liability Partnerships: Present at the Birth (Nearly), 66 U. COLO. L. REV. (forthcoming 1995). 
liability remains to be seen, ${ }^{75}$ as does the receptiveness of state bars to such limits and the circumstances under which they should operate. ${ }^{76}$

The underlying normative question, of course, implicates the justifications for partners' vicarious liability discussed above. Proponents of limits on individual partners' liability emphasize changes in the structure of the legal profession and, somewhat relatedly, business lawyers' enhanced risks of exposure to large damage awards. ${ }^{77}$ In particular, as the profession has come to include very large multi-office and multi-state firms, partners may know less about the competence and activities of their fellow partners and nonpartner associates. The relevant question is whether a profession's structural evolution and enhanced exposure to liability vitiate justifications for imposing vicarious liability. Changes in a profession's structure may, for example, increase the costs of monitoring the activities of professionals. In a large and geographically far-flung firm, effective monitoring may require more elaborate and expensive measures than would be necessary in a small firm. On the other hand, changes in the structure of professional service firms do not self-evidently reduce the costs borne by the sophisticated client who would, in the absence of derivative vicarious liability, rigorously investigate the partner with whom she directly deals and amply insure against the risk that a judgment against him will not be fully satisfied out of his individual assets and those of the firm, all perhaps in exchange for a lower fee for legal services. Nor do changes in a profession's structure enlarge the small number of clients who are that sophisticated or enhance the willingness of firms to reveal the quantitative relationship between internal monitoring and fees charged to clients.

Consider in this light the justifications for vicarious liability already set forth. The initial "benefit principle" applies with force to a large law firm, with which each member has chosen to be associated because each member anticipated direct profit and synergies less directly productive of profit through association with so many fellow professionals. Moreover, circumstances productive of legal malpractice often suggest suppressed fault on the part of fellow professionals in the firm, who many times have reason to suspect that a colleague's actions are not consistent with the profession's standards. As entities, professional services firms have few assets potentially of value to a judgment creditor, ${ }^{78}$ apart from malpractice liability insurance (which is often not mandatory ${ }^{79}$ ); if the

75. See Reuben, supra note 74.

76. See Steven C. Krane, An Ethical Lawyer's Guide to LLC Firms, N.Y.L.J., Nov. 7, 1994, at 1, col. 1 (noting divergences among jurisdictions' ethics committees on suitable modes of notice to clients).

77. See RESTATEMENT OF THE LAW GOVERNING LAWYERS $\$ 79$ n.5 (Tentative Draft No. 7, 1994) (reporting minority support within Council of American Law Institute for permitting law practice in limited liability vehicles on the basis that "the changing circumstances in which law is now practiced" make it reasonable for a legislature "to exclude the liability of a lawyer-shareholder of a professional corporation who has not been involved in the wrong out of which liability arises"). 1994).

78. See RESTATEMENT OF THE LAW GOVERNING LAWYERS $\$ 79 \mathrm{cmt}$. b (Tentative Draft No. 7 ,

79. But see DEL. CODE ANN. tit. 6, § 1546(a), (d) (1993) (registered LLP must carry at least \$1 million in liability insurance or provide $\$ 1$ million in funds segregated for satisfaction of judgments); 
"compensation principle" has normative appeal, the thinly capitalized law firm is a compelling context in which to apply it.

Statutory limits on partners' vicarious liability are, moreover, likely to reduce their incentives to monitor the conduct of fellow partners and nonpartner associates. The risk of jeopardy to partners' individual assets obviously creates a strong incentive to monitor; one might wonder, however, about the relative strength of this incentive. Partners also have incentives to monitor based on their interest in maintaining the reputation of their law firm. Moreover, if the partnership itself is vicariously liable for malpractice, partnership assets are at risk and partners not themselves implicated in the malpractice suffer reductions in their proportionate partnership interests to the extent partnership assets are used to satisfy malpractice liability. Partners might respond to this scenario in various ways: by monitoring carefully; by carrying ample amounts of liability insurance; or by reducing partnership assets through distributions, to the extent commercially feasible, prior to the ascertainment of malpractice liability. ${ }^{80}$ If the applicable organizational statute requires the firm to purchase and maintain malpractice insurance, the insurance underwriter has its own incentives to select firms less likely to generate claims against the policy. Only experience will reveal how insurer-driven efforts to monitor will compare with efforts driven by the risk of individual liability.

An additional factor contributing to uncertainty is that the structure of the statutes under discussion creates no incentive to know more rather than less about fellow professionals' activities within the same firm. Under some of the statutes, a partner has individual liability, not only for her own acts and omissions, but also for those of persons she supervised or controlled ${ }^{81}$ and for others' acts or omissions of which she had knowledge or notice. ${ }^{82}$ In the context of a professional services firm, concepts like a partner's "supervision" and "control" are apt to be malleable when applied in retrospect to partners who knew of problematic conduct and did not rectify it, a prospect that would

TEX. REV. CIV. STAT. ANN. art 6132b-3.08(d) (Supp. 1995) (registered LLP must carry at least $\$ 100,000$ in liability insurance or provide $\$ 100,000$ in segregated funds).

80. See Hamilton, supra note 74.

81. E.g., DEL. CODE ANN. tit. 6, $\$ 1515$ (c) (1993) (partner is individually liable "for his own negligence, wrongful acts or misconduct or that of any person under his direct supervision and control"); N.Y. PARTNERSHIP LAW $\$ 26$ (c) (McKinney 1995) (partner is individually liable "for any negligent or wrongful act or misconduct committed by him or her or by any person under his or her direct supervision and control while rendering professional services").

82. E.g. D.C. CODE \$ 41-146(a)(2) (Supp. 1994) (partner individually liable when partner had "written notice or knowledge of the errors, omissions, negligence, incompetence, or malfeasance that were committed by the other partner or representative at the time of occurrence"); TEX. REV. CIV. STAT. ANN. art. 61326-3.08(a)(1)(B) (Supp. 1995) (partner individually liable when partner "had notice or knowledge of the errors, omissions, negligence, incompetence, or malfeasance by the other partner or representative at the time of occurrence and then failed to take reasonable steps to prevent or cure"). Additionally, if a partner has an individual duty to monitor, breaching that duty results in direct liability. See Susan Saab Fortney, Am I My Partner's Keeper? Peer Review in Law Firm, 66 CoLo. L. REV. 329, 332 (1995). 
not encourage partners to become knowledgeable about fellow professionals' practices.

Finally, qui facit per alium, facit per se may apply with special force to law firm partners' professional relationships with each other and with their nonpartner associates. In an economy dominated by impersonal actors, professional service firms are uniquely human-based businesses. Law practice, in particular, is not a capital-intense business; human effort and judgment are the dominant factors of production. Clients may well expect members of the firm, individually, to monitor the work done under the firm's auspices. They may expect that, by holding themselves out as a single firm, members of even a large multi-site firm warrant their belief that firm work meets at least minimal professional standards. Thus, clients may expect firm members to stand behind the quality of the firm's work and to be accountable for lapses in that work's quality. They may expect members of the firm, regardless of their choice of organizational form, to have staked their professional reputations on the quality of their fellow professionals' work as well as on the quality of their own individual work. It is not evident why adding "L.L.P." or "A Professional Limited Liability Company" to the firm's letterhead should defeat those expectations.

\section{$\mathrm{V}$ \\ UNAUTHORIZED ACTS IN INVESTMENT PARTNERSHIPS}

\section{A. Recurrent Issues}

Many partnerships, especially limited partnerships, are organized to serve as investment vehicles. Such partnerships typically have distinct demarcations in function between passive investor-partners and active manager-partners, a demarcation that is formally drawn by limited partnership statutes. With some frequency, limited partners argue after the fact that the partnership is not bound by transactions entered into by general partners because the general partner's act exceeded his authority. Frequently dispositive of these disputes is the language of the limited partnership agreement defining the general partner's agency authority ${ }^{83}$; in some cases, however, the literal contents of the written agreement may not be the "last word" on authority. ${ }^{84}$ If the partnership has

83. An additional basic question is whether the transaction was within the scope of partnership business, which is a question of fact. See First W. Bank v. Livestock Yards Co., 466 N.W.2d 853, 857 (S.D. 1991). Moreover, a partner's initial authority may be restricted by subsequent modifications to the partnership agreement. A restriction on or revocation of authority is effective when the third person is notified of it. See First Nat'l Bank \& Trust Co. v. Scherr, 467 N.W.2d 427, 430 (N.D. 1991).

84. Partnership law traditionally denied a general partner authority to bind the partnership to a contract of guaranty even when the partnership agreement conferred broad authority to enter into contracts, on the basis that normally a partnership's purpose does not encompass transactions that benefit other persons but not it. See Tsakos Shipping \& Trading, S.A. v. Juniper Garden Town Homes, Ltd., 15 Cal. Rptr. 2d 585, 595 (Cal. Ct. App. 1993). The terms of the partnership agreement may alter this norm, for example by authorizing "the arrangement of financing for corporations or other entities." 
customarily entered into transactions in a particular way-for example, by relying on one co-partner to transact all business affairs-the third party may establish a course of dealing that enlarges a partner's authority. ${ }^{85}$ "Course of dealing," however, is limited by the basic agency doctrine defining apparent authority; manifestations of enhanced authority made solely by the agent do not in themselves bind the principal. ${ }^{86}$ Establishing a course of dealing that augments a partner's individual authority thus does not bind the other partners unless they knew of it and acquiesced in it.

In the most vexing cases, the limited partners themselves had reason to know of their general partner's freewheeling style, but did not object until after the last unauthorized transaction. The doctrinal dispute then focuses on ratification, that is, on whether the limited partners should be held to have consented to the transaction. More generally, the question is whether passive investor partners should be expected to monitor the general partner's activities and to attempt to rein in an errant general partner. A correlative question is the reasonableness of expecting third parties to inquire into the scope of a general partner's authority as literally defined by the written partnership agreement, and to heed such definitions in evaluating proposed transactions.

To be sure, literal language in a partnership agreement that grants the general partner unqualified or discretionary authority is subject to the general partner's fiduciary obligation toward the partnership and the other partners. In Labovitz v. Dolan, the partnership agreement gave the general partner "complete discretion in the management and control of the business and affairs of the partnership," including sole discretion to determine cash flow available for distribution to limited partners. ${ }^{87}$ The general partner made only nominal cash distributions for two years and then offered through an affiliate to buy the limited partnership interests at two-thirds of book value. The court held that the limited partners' complaint stated a triable claim for breach of fiduciary obligation because, despite the "sole discretion" language, the general partner had "a duty to exercise the highest degree of honesty and good faith in his handling of partnership assets ...."88

Nor is the general partner's right to exercise discretion unfettered even when her decision does not directly implicate partnership assets. In Desert Equities, Inc. v. Morgan Stanley Leveraged Equity Fund, II, L.P., the general partner had discretionary authority under the partnership agreement to "excuse" a limited partner from participation (via additional capital contributions) in new investments, on the basis of the general partner's determination that such participation would have a material adverse effect on the investment, the partnership, or

In re Securities Group, 926 F.2d 1051, 1054 (11th Cir. 1991).

85. See Harper v. Delaware Valley Broadcasters, Inc., 743 F. Supp. 1076, 1090 (D. Del. 1990), aff'd, 932 F.2d 959 (3d Cir. 1991); Smith v. Dixon, 386 S.W.2d 244, 246 (Ark. 1965).

86. See RESTATEMENT (SECOND) OF AGENCY $\$ 8$ (1958).

87. 545 N.E.2d 304, 306 (Ill. App. Ct. 1989), appeal denied, 550 N.E.2d 557 (IIl. 1990).

88. Id. at 310; accord Knopke v. Knopke, 837 S.W.2d 907, 915 (Mo. Ct. App. 1992). 
the general partner. ${ }^{89}$ The general partner excused the plaintiff from further participation in new investments after the plaintiff sued the general partner over a dispute arising out of a prior limited partnership in which the plaintiff also invested. The court held that the plaintiff's claim that the general partner acted in bad faith and in a retaliatory manner could not be resolved without a trial. ${ }^{90}$

Such limits on the general partner's authority primarily affect its duties to the partnership and to limited partners. That the general partner has breached duties owed to the partnership itself or to the limited partners does not directly implicate the interests of third parties. ${ }^{91}$ If, however, the third party assists in or knowingly benefits from the general partner's breach of fiduciary duty, principles of restitution ${ }^{92}$ and of tort law $^{93}$ create liability toward the limited partners and the partnership. Furthermore, a partner lacks power, without fellow partners' assent, to assign specific partnership assets as security for the partner's individual debts, which makes a contravening assignment void. ${ }^{94}$ Finally, a third party may not rely on the apparent authority of an agent to do an act if circumstances suffice to place the third party on notice that the agent is thereby breaching a duty owed to his principal. ${ }^{95}$

\section{B. The Kroh Collapse and Similar Incidents}

Several recent disputes over a general partner's authority to bind the partnership raise questions about the business practices of third parties with whom the general partner dealt. A surprisingly large proportion of relevant recent cases involve corporate general partners affiliated with Kroh Brothers,

89. 624 A.2d 1199, 1201-02 (Del. 1993).

90. Id at 1207. Having moved for judgment on the pleadings, the general partner conceded for purposes of its motion that the plaintiff's factual allegations of bad faith and retaliation were true. Id. at 1206 . The trial court held that the general partner was obliged to exercise its discretion in a reasonable manner. Id.

91. Third-party interests may be implicated by limits imposed by agency doctrine on the imputation of knowledge or notice to partners. If a partner acquires knowledge or receives notice in the course of committing a fraud on the partnership or consenting to the commission of a fraud, that knowledge or notice is not imputed to the partnership. See RUPA \& 102(f), 6 U.L.A. at 287 (Supp. 1995); In re Mediscan Research, Ltd., 940 F.2d 558, 563-64 n.6 (9th Cir. 1991). See generally RESTATEMENT (SECOND) OF AGENCY $§ 282$ (1958). Partners acting in concert to breach their fiduciary duties to the partnership may not rely on each other's knowledge of wrongdoing to establish knowledge on the part of the partnership. See Beerman v. Graff, 621 N.E.2d 173, 177-78 (Ill. App. Ct. 1993).

Some jurisdictions recognize exceptions to the basic principle of nonimputation when the victim of the agent's fraud is a wholly innocent third party on the rationale that the loss produced by the agent's fraud should be borne by the principal, who chose the agent. Separately, the adverse interest rule is inapplicable in some jurisdictions when the agent is the principal's sole representative. For a recent application of these exceptions in the partnership context, see KE Property Management Inc. v. 275 Madison Management Corp., 1993 WL 285900 (Del. Ch., July 27, 1993).

92. See RESTATEMENT OF RESTITUTION $\$ 138$ (1937) (third person who colludes with fiduciary in committing breach of duty and obtains benefit therefrom has duty to make restitution to beneficiary).

93. See RESTATEMENT (SECOND) OF TORTS $\$ 871 \mathrm{cmt} . \mathrm{c}$ (1979) (person who assists fiduciary in committing breach of trust is subject to liability for harm caused).

94. See UPA § 25(2)(a), 6 U.L.A. at 326; RUPA § 401(g), 6 U.L.A. at 309 (Supp. 1995).

95. See In re West Tech, Ltd., 882 F.2d 323, 325 (8th Cir. 1989); cf. RESTATEMENT (SECOND) OF AGENCY $\$ 39$ (1958) (unless otherwise agreed, agent's authority to act as agent is only to act for principal's benefit). 
a real estate company. Prior to its financial collapse in 1987, Kroh Brothers financed many real estate projects by syndicating project-specific ownership interests through separate limited partnerships, with a Kroh-owned corporation serving as general partner. Although the partnership agreements required each partnership to maintain a separate bank account and to deposit all funds received by the partnership into that account, Kroh's practice was to maintain a single bank account, controlled by a Kroh corporate affiliate, into which all limited partnership funds were deposited and commingled. ${ }^{96}$ Kroh general partners, in several instances, borrowed money, secured the loan with a mortgage on the property of a limited partnership, and then used the loan proceeds for purposes not related to those of the particular indebted partnership. ${ }^{97}$ These transactions contravened language in partnership agreements that required each partnership to have a separate bank account and that prohibited commingling, ${ }^{98}$ as well as language in at least some of the partnership agreements that required transactions to be "reasonably related to the achievement of the purposes of the partnership." Some transactions also contravened a prohibition on recourse loans. ${ }^{100}$ Interestingly, a separate provision of the Kroh partnership agreements provided that persons dealing with the partnership "are entitled to rely conclusively on the power and authority of the General Partner as set forth in this agreement [and] in no event shall any person dealing with the general partner ... be obligated to ascertain that the terms of this agreement have been complied with ...."101 The same provision stated that each instrument executed by the General Partner "shall be conclusive evidence in favor of any and every person relying thereon . . . "102 Several Kroh lenders, having reviewed the entire partnership agreement, knew its other terms clearly contradicted the breadth of authority otherwise supported by these provisions. ${ }^{103}$

In post-bankruptcy disputes, Kroh lenders lost because their dealings with representatives of Kroh general partners did not generate enforceable claims against limited partnership property; lenders triumphed only when they had

96. Green River Assocs. v. Mark Twain Kan. City Bank, 808 S.W.2d 894, 900 (Mo. Ct. App. 1991) (Kennedy, J., dissenting).

97. See In re 9221 Assocs., 973 F.2d 671, 672 (8th Cir. 1992), cert. denied, 113 S. Ct. 1283 (1993); In re Fox Hill Office Investors, Ltd., 926 F.2d 752, 753 (8th Cir. 1991); West Tech, 882 F.2d 323; Anchor Centre Partners, Ltd. v. Mercantile Bank, N.A., 803 S.W.2d 23, 29 (Mo. 1991); Green River Assocs., 808 S.W.2d at 896-97. 896.

98. See Fox Hill, 926 F.2d at 754; West Tech, 882 F.2d at 325; Green River Assocs., 808 S.W.2d at

99. See In re West Tech Ltd., 104 B.R. 176, 178 (Bankr. W.D. Mo. 1988), aff'd, 882 F.2d 323 (8th Cir. 1989).

100. See Fox Hill, 926 F.2d at 754 .

101. Id. at $753-54$ n.4:

102. See id.

103. See id. at 754 . The underlying basic principle of contract interpretation is that a partnership agreement should be interpreted as an entirety, and interpretations of provisions should be avoided when they unnecessarily render meaningless other provisions. See Leon Ltd. v. Albuquerque Commons Partnership, 862 S.W.2d 693, 703-04 (Tex. Ct. App. 1993). 
obtained irrevocable and transferable letters of credit to enforce limited partners' commitment to make capital contributions. ${ }^{104}$ What is intriguing about these cases is that in many of them, the limited partners had reason to suspect-and some clearly had actual knowledge - that the general partner was violating provisions of the partnership agreement. Limited partners appear to have received distribution checks drawn on the common bank account into which limited partnership funds were deposited and commingled. ${ }^{105}$ This fact was not, however, helpful to the Kroh lenders, who were unable to identify any statement or act of the limited partnerships that directed payment of loan proceeds away from the partnership into a common Kroh account. ${ }^{106}$ The Kroh lenders, moreover, having paid funds into the account of a nonfiduciary Kroh vehicle, lost the protection afforded by section 2 of the Uniform Fiduciaries Act, which provides that a person who pays a fiduciary is not responsible for the fiduciary's application of the funds paid. ${ }^{107}$

One implication of the Kroh cases, and of other cases like them, ${ }^{108}$ is that limited partners are not their general partner's keeper. As passive investors, their obligations do not include monitoring the general partner's conduct of business for the benefit of third parties. Even limited partners who know that the general partner is violating the partnership agreement effectively owe no duty to third parties to rein in the general partner. This point underlies limited partnership statutes, which penalize limited partners who act in a manner "substantially the same" as general partners or who lead third parties to believe they possess the prerogatives of a general partner.

These conclusions are reinforced by the restrictive operation of the agency doctrine of ratification. A principal may expressly or impliedly adopt the act of someone purporting to act as his agent. If the principal knows the facts about the agent's act and accepts its benefits, the principal has ratified the act. ${ }^{109}$ Agency doctrine, under some circumstances, infers that an unauthorized transaction has been affirmed from a failure to repudiate it. ${ }^{110}$ Such circumstances are those "that, according to the ordinary experience and habits of men, one would be naturally expected to speak if he did not con-

104. See Jones v. Boatmen's First Nat'l Bank, 813 S.W.2d 1, 2-3 (Mo. Ct. App. 1991). By contrast, in Anchor Centre the lender was not entitled to draw on letters of credit due to defects in the transfer of the letters to it. See Anchor Centre, 803 S.W.2d at 34-35.

105. See Green River Assocs., 808 S.W.2d at 900.

106. Id. at 897 n.2.

107. See id. at 897-98 (holding Mo. REV. STAT. $\$ 456.250$ (1992) inapplicable). See generally UNIFORM FIDUCIARIES ACT $\S 2,7$ A U.L.A. $\$ 401$ (1985).

108. See, e.g., Schrammeck v. FSLIC, 853 P.2d 702 (Mont. 1993) (lender knew partner lacked authority to bind partnership in loan transaction; lender received no interest in property that purportedly collateralized loan); Evans v. Pioneer Bank, 809 P.2d 251 (Wyo. 1991) (lender knew that partnership agreement required consent by all managing partners to execution of promissory note; lender failed to prove consent).

109. See Restatement (SECOND) OF AGENCY $\$ 98$ (1958).

110. Id. § 94. 
sent ...." "Ordinary experience and habits" do not create an expectation that one will speak about transactions of which one is then unaware. ${ }^{112}$ That is, the focus and effect of ratification are particularized to specific acts and transactions and to whether they were known to the principal. ${ }^{113}$ In the Kroh cases, limited partners' knowledge that funds had been commingled is clearly different from knowledge of specific loan transactions and specific mortgage interests created in partnership property. To be sure, many limited partners in Kroh ventures had reason to make further inquiry of their particular partnership's general partner, but their failure to do so is not deemed an affirmation of the general partner's universe of unauthorized transaction. ${ }^{114}$

\section{CONCLUSION}

Agency-related disputes in the partnership context typically involve the competing claims of two worthy objectives: reducing costs and delay otherwise attendant upon transactions and commercial relationships involving a partnership and third parties, and limiting in a fair and reasonable fashion the financial risks of membership in a partnership. Many agency doctrines have the effect of reducing adverse consequences for third parties who, dealing with an individual partner, do not make exhaustive inquiry into the partner's authority and do not insure against the consequences that will follow if the partner's act is unauthorized or is wrongful. In the absence of these doctrines, vigilant third parties would incur costs in investigating and insuring, and transactions would be delayed. The result would frequently be commercial entropy. Agency doctrines also, however, operate to limit the perils of partnership to the consequences of authorized conduct. To be sure, agency encompasses doctrines of apparent and inherent authority that can augment a partner's express authority, but their operation is limited by the nature of the partnership's business as defined by its members' express agreement and conduct.

111. Id. cmt. a. Mere silence is not acquiescence when the other party knows that the silent partner has not consented to the transaction. See Spencer v. Riordan, 608 N.E.2d 432, 438 (IIl. App. Ct. 1992), appeal denied, 612 N.E.2d 524 (Ill. 1993).

112. See, e.g., In re Securities Group, 926 F.2d 1051, 1055 (11th Cir. 1991) (evidence demonstrated partnership benefitted from guaranty transactions and had detailed knowledge of them); S\&B Mining Co. v. Northern Commercial Co., 813 P.2d 264, 268 (Alaska 1991) (no genuine issue of material fact on ratification question when partner "clearly had knowledge" of note transaction).

113. The knowledge requisite to ratification may be very particular: for example, a limited partner's knowledge that a partnership construction project is experiencing cost overruns does not ratify the general partner's unauthorized payments of overruns if the limited partner does not know either the overrun amounts or that the general partner is paying them out of partnership assets. See Reeve $v$. Folly Hill Ltd. Partnership, 628 N.E.2d 36, 38-39 (Mass. App. Ct. 1994).

114. Similarly restrictive is the agency doctrine of imputed knowledge. Knowledge an agent acquired while acting on the principal's behalf is imputed to the principal, on the basis that the agent has a duty to disclose such information to the principal. Knowledge that the agent should have acquired, but did not, is not imputed. See Thomas v. N.A. Chase Manhattan Bank, 1 F.3d 320, 325 (5th Cir. 1993). The principal is affected by "should have acquired" information when it owes a duty to others that care be used in acquiring such information. See RESTATEMENT (SECOND) OF AGENCY $\$ 277$ (1958). 